VARIACIONES ESPACIOTEMPORALES DE LA FAUNA MACROBENTÓNICA DE UNA PLAYA ARENOSA Y SU RELACIÓN CON LOS CAMBIOS DEL PERFIL DE PLAYA Y EL TAMAÑO DE GRANO DE LOS SEDIMENTOS, EN PLAYA EL PELÍCANO, BAJA CALIFORNIA

\title{
SPACE-TIME VARIATIONS IN MACROBENTHIC FAUNA OF A SANDY BEACH, RELATED TO CHANGES IN THE BEACH PROFILE AND SEDIMENT GRAIN SIZE, AT EL PELÍCANO BEACH, BAJA CALIFORNIA
}

\author{
Luis Antonio Cupul-Magaña \\ Miguel Agustín Téllez-Duarte \\ Facultad de Ciencias Marinas \\ Universidad Autónoma de Baja California \\ Apartado postal 453 \\ Ensenada 22800, Baja California, México
}

Recibido en enero de 1997; aceptado en septiembre de 1997

\section{RESUMEN}

Se describen las variaciones espaciotemporales de la biocenosis macrobentónica en relación con los cambios en la morfología del perfil de playa y las características texturales del sedimento de Playa El Pelícano, al sur de San Felipe, Baja California, México. Los muestreos se llevaron a cabo en los meses de marzo, mayo, septiembre y noviembre de 1993. Se estableció un perfil de playa donde se ubicaron las estaciones fijas de muestreo desde el límite superior de pleamar hasta el límite inferior de bajamar. Las matrices con datos de abundancia obtenidas fueron analizadas mediante un análisis aglomerativo de modo $Q$, para establecer los cambios estructurales de la comunidad y compararlos con los cambios en el perfil de playa y con el tamaño de grano del sedimento. En general, se obtuvo que el número de especies fue consistentemente bajo y que éstas variaron en función del cambio en las características texturales del sedimento y de la morfología del perfil de playa. La única especie dominante en todos los muestreos y niveles del perfil de playa fue el gasterópodo Nassarius iodes, ya que tiende a seguir la marea para permanecer en el vaivén del oleaje, donde las condiciones de alimen-tación son óptimas. Estos cambios en la estructura de la comunidad en esta playa arenosa hacen ver que la interpretación ecológica y paleoecológica de estos ambientes costeros comparables es muy compleja, debido a la variabilidad espaciotemporal de las condiciones ambientales, tanto en el aspecto biótico como abiótico.

Palabras clave: perfil de playa, sedimento, ecología, paleoecologia, Golfo de California.

\begin{abstract}
Time-space variations in macrobenthonic biocenosis are described in relation to the morphology of the beach profile and textural characteristics of the sediment at El Pelicano Beach, south of San Felipe, Baja California, Mexico. Sampling was carried out in March, May, September and November 1993 along a beach profile, at fixed stations from the higher high tide to the lower low tide. Abundance data matrices were analyzed by applying a $Q$-mode cluster analysis, in order to establish community structural changes and compare them with changes in the beach profile and sediment grain size. In general, the number of species was consistently low and varied with the textural characteristics
\end{abstract}


of the sediment and the morphology of the beach profile. Only the gastropod Nassarius iodes was dominant in all the samplings and beach profile lcvels, because of its tendency to follow the tide in order to remain in the swash zone where feeding conditions are optimum. Community structural changes at El Pelícano Beach indicate that the ecological and paleoecological interpretation of comparable coastal environments is complex, because of the biotic and abiotic time-spacc variability.

Key words: beach profile, sediment, ecology, paleoecology, Gulf of California.

\section{INTRODUCCIÓN}

Las playas arenosas representan uno de los ambientes marinos más severos para las comunidades de animales macrobentónicos, ya que éstas se encuentran controladas por procesos físicos (oleaje y corrientes) y geológicos (sedimentación, tamaño de grano y transporte de sedimentos) que moldean la costa. Investigadores como Komar (1976), Hanson (1989) y Souyhgate (1989) han relacionado los parámetros de oleaje y sedimentación con la morfodinámica de la playa.

Algunos animales de comunidades de playas arenosas influyen profundamente el ambiente fisico por medio de la actividad bioperturbadora en los sedimentos, lo cual puede afectar propiedades como contenido de agua, distribución del tamaño de grano y contenido de materia orgánica. Este efecto sobre el sedimento, sumado a la competencia por el espacio, a las relaciones comensales e interacciones entre depredador y presa, son un componente importante en la integración de la estructura de estas comunidades (Sanders, 1960; Rhoads y Young 1970).

La distribución del macrobentos en playas arenosas exhibe un parchado, una zonación y fluctuaciones que son debidas a la marea y a las migraciones de los organismos. El parchado resulta principalmente de una clasificación pasiva producida por las olas, la localización del alimento, las variaciones en la penetrabilidad de la arena y de las agregaciones biológicas (McLachlan y Hesp, 1984); aunado a esto se encuentra el tipo de sustrato y el periodo de sumergencia como factores que controlan la distribución de la fauna (Fürsich y Flessa, 1987). Lo anterior sugiere que las características faunísticas de una playa arenosa son complejas y están determinadas por la morfología y dinámica de la playa, más que por un solo

\section{INTRODUCTION}

Sandy beaches are some of the harshest environments for macrobenthic animal communities, because they are controlled by physical (swell and currents) as well as geological processes (sedimentation, grain size and sediment transport) that shape the coast. Researchers such as Komar (1976), Hanson (1989) and Souyhgate (1989) have related wave and sedimentation parameters to the morphodynamics of the beach.

Some animals of sandy beach communities severely impact the physical environment through bioturbation of the sediments, which affects water content, grain size distribution and organic matter content. This effect on the sediment, as well as the competition for space, commensal relationships and predator-prey interactions are an integral part of the community structure (Sanders, 1960; Rhoads and Young, 1970).

The distribution of macrobenthos of sandy beaches exhibits patchiness, zonation and fluctuations regulated by the tide and migration of organisms. This patchiness results from a passive sorting produced by waves, food availability, variations in the penetrability of the sand and biologic aggregations (McLachlan and Hesp, 1984). Substrate type and period of submergence also control faunal distribution (Fürsich and Flessa, 1987). This suggests that the faunistic characteristics of a sandy beach are complex and are determined by the morphology and dynamics of the beach and not by just one parameter, which makes it difficult to interpret the paleoecology of ancient sandy beach deposits.

This study describes the space-time variations of the macrobenthic biocenosis and their relationship with morphological changes in the beach profile and the textural properties of the 
parámetro, lo que dificulta la interpretación paleoecológica de antiguos depósitos de playas arenosas.

El presente trabajo describe las variaciones espaciotemporales de la biocenosis macrobentónica y su relación con los cambios en la morfología del perfil de playa y las características texturales del sedimento de una playa arenosa en el noroeste del Golfo de California, con el fin de evaluar su uso potencial en la interpretación de playas antiguas.

\section{ÁREA dE ESTUdio}

El área de estudio se conoce localmente como Playa El Pelícano; se localiza a los $30^{\circ} 45^{\prime}$ de latitud Norte y $114^{\circ} 42^{\prime}$ de longitud Oeste, a $33 \mathrm{~km}$ al sur de San Felipe, Baja California, México (fig. 1). Es una playa arenosa y recta, con una berma amplia y un campo de dunas en una costa abierta, con una pendiente de la playa muy pronunciada y una extensa planicie intermareal de aproximadamente $200 \mathrm{~m}$.

\section{METODOLOGÍA}

Con el objeto de detectar las variaciones en la morfodinámica de la playa, se llevaron a cabo cuatro muestreos en los meses de marzo, mayo, septiembre y noviembre de 1993; de esta manera se consideraron los periodos en donde se reflejan los cambios más notables en la distribución de los organismos y en los perfiles de playa.

Se estableció un transecto perpendicular a la playa desde el límite de marea alta hasta el límite de marea baja, levantándose el perfil de playa por medio de nivelación diferencial. Se consideraron condiciones de mareas vivas, esto con la finalidad de obtener el máximo de playa descubierta. De acuerdo con las características morfológicas del perfil de playa, se definieron las estaciones de muestreo: estación A, correspondiente a la cara de la playa; estación $\mathrm{B}$, la planicie de marea interna; estaciones $\mathrm{C}$ y $\mathrm{D}$, la planicie de marea media; y estación $\mathrm{E}$, la planicie de marea externa.(tabla 1); éstas se muestrearon en el mismo sitio durante cada periodo de muestreo. En cada estación se recolectaron sediment of a sandy beach in the northwest Gulf of California, in order to evaluate its potential for interpreting ancient beaches.

\section{STUDY AREA}

The study area, locally called El Pelícano Beach $\left(30^{\circ} 45^{\prime} \mathrm{N}, 114^{\circ} 42^{\prime} \mathrm{W}\right)$, is located $33 \mathrm{~km}$ south of San Felipe, Baja California, Mexico (fig. 1). It is a straight, sandy beach, with a wide berm and dune field on an open coast that has a very pronounced beach slope and an extensive intertidal flat of approximately $200 \mathrm{~m}$.

\section{METHODS}

Four samplings were conducted during March, May, Scptember and November 1993 to detect variations in the morphodynamics of the beach; in this way, the periods that present the most notable changes in the distribution of the organisms and in the beach profiles were considered.

A transect was set up perpendicular to the beach from the higher high tide to the lower low tide. A beach profile was made from the differences in the levels. Spring tides were examined in order to obtain the maximum exposed beach. The sampling stations were determined according to the morphological characteristics of the beach profile: station A, corresponds to the beach face; station $B$, the internal tidal flat; stations $\mathrm{C}$ and $\mathrm{D}$, the middle tidal flat; and station $\mathrm{E}$, the external tidal flat (table 1). The same site was sampled at each station. Sediment samples were collected from each station for textural analysis in the laboratory, according to Folk's (1980) method.

The macrobenthic organisms were obtained by sampling with replacement in $0.5 \times 1.0 \mathrm{~m}$ quadrants, digging down to $25 \mathrm{~cm}$, and collecting only one specimen per species to be identified in the laboratory. The samples were passed through a $0.5-\mathrm{mm}$-mesh sieve, simultaneously counting the organisms retained.

$\wedge Q$-mode cluster analysis with singlc linkage Euclidean distances was applied to determine the structural changes in the 


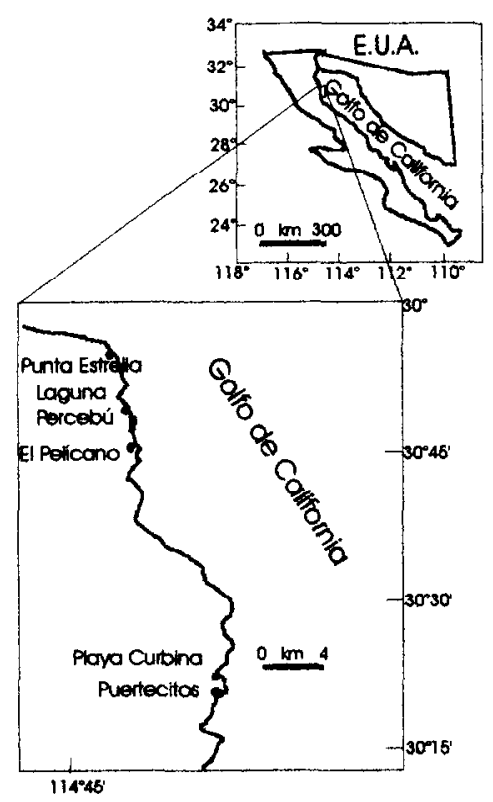

Figura 1. Localización del área de estudio.

Figure 1. Location of the study area.

Tabla 1. Ubicación de los niveles dentro del perfil de playa.

Table 1. Location of the levels within the beach profile.

\begin{tabular}{cccl}
\hline Estación & $\begin{array}{c}\text { Distancia } \\
\text { entre estaciones } \\
(\mathrm{m})\end{array}$ & $\begin{array}{c}\text { Zona de ubicación } \\
\text { en el } \\
\text { perfil de playa }\end{array}$ & Características fisicas del ambiente \\
\hline A & 0 & Cara de la playa & $\begin{array}{l}\text { Sección con la pendiente más pronunciada } \\
\text { del perfil de playa. Sedimentos gruesos y } \\
\text { fragmentos de conchas. }\end{array}$ \\
B & 16 & $\begin{array}{c}\text { Planicie de } \\
\text { marea interna }\end{array}$ & $\begin{array}{l}\text { Sección separada de la anterior por un } \\
\text { canal de drenaje de marea. Presenta } \\
\text { sedimentos de arenas gruesas a medias; } \\
\text { escasos fragmentos de conchas. }\end{array}$ \\
Planicie con poca pendiente. Presenta \\
C
\end{tabular}


Tabla 2. Algunas características fisicas de Playa El Pelícano, incluyendo los intervalos de marea y nivel de marea de bajamar inferior referidos al nivel medio del mar, la longitud del perfil de playa descubierta muestreada durante la bajamar y el tamaño medio de grano.

Table 2. Some physical characteristics of El Pelícano Beach, including the tide ranges, mean lower low water, length of the exposed beach profile sampled during low tide and mean grain size.

\begin{tabular}{cccccc}
\hline $\begin{array}{c}\text { Fecha } \\
(\mathrm{dia} / \mathrm{mes} / \mathrm{año})\end{array}$ & $\begin{array}{c}\text { Intervalo } \\
\text { de mareas } \\
(\mathrm{m})\end{array}$ & $\begin{array}{c}\text { Nivel de } \\
\text { marea baja } \\
(\mathrm{m})\end{array}$ & $\begin{array}{c}\text { Longitud } \\
\text { descubierta } \\
\text { del perfil } \\
(\mathrm{m})\end{array}$ & $\begin{array}{c}\text { Promedio } \\
\text { del tamaño } \\
\text { de grano } \\
(\mathrm{phi})\end{array}$ & $\begin{array}{c}\text { Intervalo del } \\
\text { tamaño medio } \\
\text { de grano } \\
(\mathrm{phi})\end{array}$ \\
\hline $24 / 03 / 93$ & 4.92 & -2.58 & 139 & 1.25 & $0.98-1.80$ \\
$03 / 05 / 93$ & 5.39 & -2.61 & 139 & 1.75 & $1.00-2.70$ \\
$02 / 09 / 93$ & 4.63 & -2.09 & 139 & 1.64 & $0.9-2.80$ \\
$30 / 11 / 93$ & 5.03 & -2.55 & 134 & 1.43 & $0.89-2.15$ \\
\hline
\end{tabular}

muestras de sedimentos para su posterior análisis textural en el laboratorio, según el método de Folk (1980).

La obtención de los organismos macrobentónicos se realizó mediante un muestreo con remplazo utilizando cuadrantes de $0.5 \times 1.0 \mathrm{~m}$; se excavó a una profundidad de $25 \mathrm{~cm}$ en el sedimento y se recolectó sólo un ejemplar por especie para su posterior identificación en el laboratorio. La muestra se pasó a través de un tamiz con luz de malla de $0.5 \mathrm{~mm}$, contándose simultáneamente los organismos obtenidos.

Para establecer los cambios estructurales del macrobentos relacionados con cambios en las características físicas del sustrato, se aplicó un análisis aglomerativo modo $Q$ de distancias euclidianas de cadena sencilla y se graficaron en dendrogramas para estimar el grado de similitud entre las estaciones a lo largo del tiempo y conocer si existen agrupaciones que nos determinen un patrón de distribución; para esto se utilizó el paquete estadístico STATISTICA, versión 4.2 para Windows. Los resultados se compararon con las variaciones existentes en la morfología del perfil de playa y con el tamaño de grano de los sedimentos en cada estación.

\section{RESULTADOS}

\section{Ambiente fisico}

Algunos de los parámetros físicos que caracterizan al área de estudio se presentan en la macrobenthos related to changes in the physical characteristics of the substrate. They were plotted in dendrograms to estimate the degree of similarity among the stations through time and determine possible clusters that would define a distribution pattern. The computer program STATISTICA, version 4.2 for Windows, was used. The results were compared with the morphological variations of the beach profile and the sediment grain size at each station.

\section{RESULTS}

\section{Physical environment}

Some of the physical parameters that characterize the study area are shown in table 2. The mean tide level at El Pelícano Beach was from 4.63 to $5.39 \mathrm{~m}$.

The results of the granulometric analysis for the four sampling periods are shown in table 3. Coarse sediment ( 1.0 on the phi scale) dominates the beach face and internal tidal flat. There are marked variations at stations $\mathrm{D}$ and $\mathrm{E}$ throughout the study (fig. 2); the grain size changes from coarse sand in March to fine sand in November, related to changes in the beach profile caused by the strong tidal currents that occur in this area.

Figure 3 shows the beach profiles. In March, the morphology of the beach profile is characterized by a wide berm and pronounced 
Tabla 3. Resultados del análisis granulométrico de los cuatro periodos de muestreo en Playa El Pelícano. El tamaño medio de grano está en unidades phi; ag = arena gruesa, am = arena media, af = arena fina y amf $=$ arena muy fina.

Table 3. Results of the granulometric analysis of the four sampling periods at El Pelicano Beach. The mean grain size is in phi units; ag = coarse sand, $a m=$ medium sand, af = fine sand and amf $=$ very fine sand.

\begin{tabular}{cclccc}
\hline Nivel & Fecha & Phi & Nivel & Fecha & Phi \\
\hline A1 & marzo 1993 & $0.98 \mathrm{ag}$ & $\mathrm{C} 3$ & septiembre 1993 & $0.95 \mathrm{ag}$ \\
A2 & mayo 1993 & $1.0 \mathrm{ag}$ & $\mathrm{C} 4$ & noviembre 1993 & $1.3 \mathrm{am}$ \\
A3 & septiembre 1993 & $0.9 \mathrm{ag}$ & $\mathrm{D} 1$ & marzo 1993 & $1.0 \mathrm{ag}$ \\
A4 & noviembre 1993 & $0.95 \mathrm{ag}$ & $\mathrm{D} 2$ & mayo 1993 & $2.7 \mathrm{af}$ \\
B1 & marzo 1993 & $1.0 \mathrm{ag}$ & $\mathrm{D} 3$ & septiembre 1993 & $2.65 \mathrm{af}$ \\
B2 & mayo 1993 & $1.2 \mathrm{am}$ & $\mathrm{D} 4$ & noviembre 1993 & $1.9 \mathrm{am}$ \\
B3 & septiembre 1993 & $0.9 \mathrm{ag}$ & $\mathrm{E} 1$ & marzo 1993 & $1.8 \mathrm{am}$ \\
B4 & noviembre 1993 & $0.89 \mathrm{ag}$ & $\mathrm{E} 2$ & mayo 1993 & $1.9 \mathrm{am}$ \\
C1 & marzo 1993 & $1.5 \mathrm{am}$ & $\mathrm{E} 3$ & septiembre 1993 & $2.8 \mathrm{af}$ \\
C2 & mayo 1993 & $1.98 \mathrm{am}$ & $\mathrm{E} 4$ & noviembre 1993 & $2.15 \mathrm{af}$ \\
\hline
\end{tabular}

tabla 2. El intervalo del nivel medio de marea en Playa El Pelícano fue de 4.63 a $5.39 \mathrm{~m}$.

Los resultados del análisis granulométrico para los cuatro periodos de muestreo se presentan en la tabla 3. Podemos notar que el sedimento más grueso ( 1.0 en la escala phi) es predominante en la cara de la playa y en la planicie de marea interna; sin embargo, existen marcadas variaciones en las estaciones $\mathrm{D}$ y $\mathrm{E}$ a lo largo del estudio (fig. 2), ya que el tamaño de grano cambia de arenas gruesas en marzo a arenas finas en noviembre. Este comportamiento está relacionado con los cambios en el perfil de playa debido a las fuertes corrientes de mareas que se presentan en esta zona.

En la fig. 3 se presentan los perfiles de playa. En marzo el perfil de playa tiene una morfologia caracterizada por una berma amplia y pendiente pronunciada, la cual continúa a lo largo de la planicie de marea, finalizando con la presencia de un gran canal de desagüe de la marea. Esto nos da una idea clara de qué tan intensos son los procesos por corrientes de mareas en una costa expuesta donde los intervalos de marea son de hasta $8 \mathrm{~m}$. En el perfil de mayo no se puede hablar de una crosión neta, aunque hay una remoción de sedimentos de la planicie de marea media, pero ésta sirve para rellenar el canal observado en marzo, aparentando un slope that continues along the tidal flat until reaching a large tidal drainage canal. This indicates the intensity of the tidal currents in an exposed coast where the tide range is up to $8 \mathrm{~m}$. The profile for May does not provide any information on net erosion, even though sediment was removed from the middle tidal flat. This sediment fills in the canal observed in March, simulating a shoreward displacement of the tidal drainage canal. Around September, the canal is completely covered and a sand bar, some $30 \mathrm{~m}$ wide, appears. In November, the bar moves shoreward and the large tidal drainage canal reappears.

\section{Fauna}

Nassarius iodes and Olivella dama were observed in the March sampling at station A, where the substrate is poorly-sorted coarse sand $(0.98$ phi) with shell fragments. The number of individuals of $N$. iodes increased and Donax navicula appeared at station $\mathrm{B}$, where the substrate is coarse sand ( $1.0 \mathrm{phi})$, with some shell fragments. The tidal drainage canal was located between stations A and B. Specimens of $N$. iodes, $O$. dama and $D$. navicula were found at station C. Only $N$. iodes was observed at station $\mathrm{D}$, while $O$. dama and many individuals 


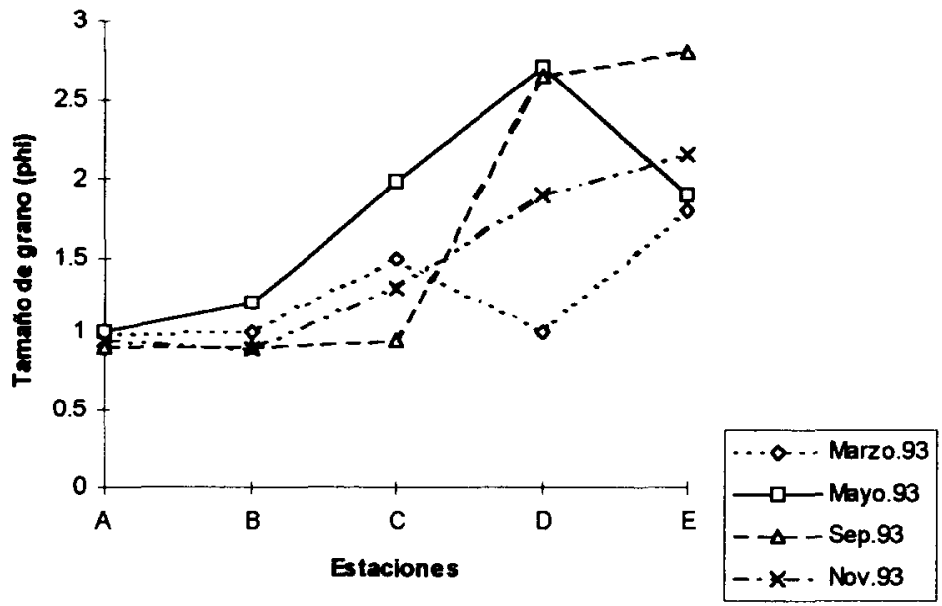

Figura 2. Distribución de tamaños de grano de Playa El Pelícano, durante los cuatro periodos de muestreo.

Figure 2. Grain-size distribution at El Pelícano Beach, during the four sampling periods.

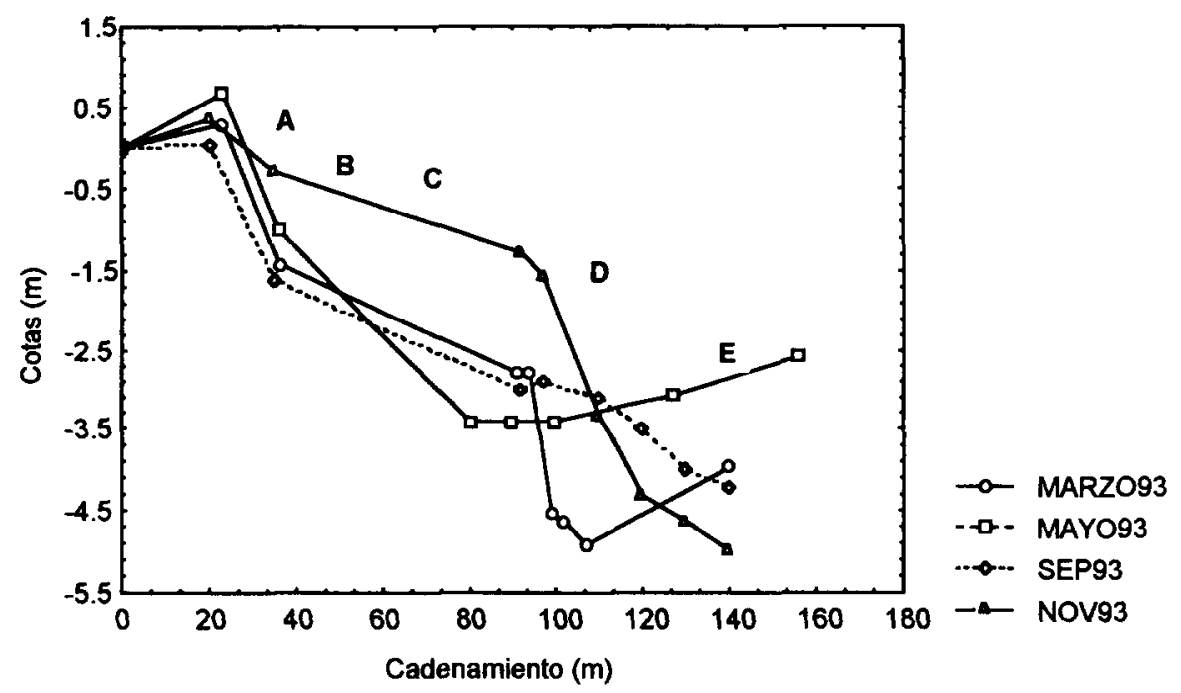

Figura 3. Perfiles de playa durante los cuatro periodos de muestreo en Playa El Pelícano; se muestra también la ubicación de las estaciones de muestreo.

Figure 3. Beach profiles of the four sampling periods at El Pelicano Beach; the sampling sites are also indicated. 
desplazamiento del canal de desagüe de marea hacia la costa. Hacia sepliembre, el canal se encuentra cubierto completamente y se ha formado una barra arenosa de unos $30 \mathrm{~m}$ de ancho. Por último, en noviembre la barra se mueve hacia la costa y aparece de nuevo el gran canal de desagüe de marea.

\section{Fauna}

En el muestreo de marzo en la estación A, donde el sustrato es de arena gruesa (0.98 phi) mal clasificado con fragmentos de conchas, se encontraron Nassarius iodes y Olivella dama. En la estación B aumentaron los individuos de $N$. iodes y aparece Donax navicula; en esta estación el sustrato sigue arena gruesa (1.0 phi) con pocos fragmentos de concha. Entre las estaciones A y $\mathrm{B}$ se presentó un canal de drenaje de marea. En la estación $\mathrm{C}$ se encontraron individuos de $N$. iodes, $O$. dama y $D$. navicula. En la estación $\mathrm{D}$ únicamente se encontró $N$. iodes, mientras que en la estación $\mathrm{E}, O$. dama y una gran abundancia de $N$. iodes; las caracteristicas sedimentarias son de arenas gruesas a medias. Cabe señalar que $N$. iodes se mantiene en todos los niveles (fig. 4a).

En el muestreo de mayo, la persistencia de $N$. iodes se mantiene en los cinco niveles, siendo su mayor abundancia en la estación A, en donde se volvió a encontrar individuos de $O$. dama; el sedimento presenta características muy similares al muestreo anterior. En la estación B no se encontraron otros organismos asociados con $N$. iodes, mientras que en la estación $\mathrm{C}$ se presentaron $O$. dama, $D$. navicula y Mellita longfisa. En la estación D sólo se encontró $N$ iodes y en la estación E, $N$. iodes, Diplodonta orbella, $O$. dama, Donax navicula y $M$. longfisa (fig. 4b).

En el muestreo de septiembre, se observó que $N$. iodes sólo está presente en los niveles $\mathrm{B}$, C y D; además, solamente se observan organismos de $D$. navicula y $D$. orbella en la estación $C$ y $M$. longfisa en la estación D (fig. 4c). Es notable el incremento en el tamaño de grano y la presencia de abundantes fragmentos $y$ conchas en la cara de la playa, así como un aparente cambio en la morfología del perfil, mientras que en los niveles D y E el sedimento fue de arenas finas ( 2.65 a $2.8 \mathrm{phi})$. of $N$. iodes were observed at station $\mathrm{E}$; the sediments present coarse to medium sand. Nassarius iodes was observed in all levels (fig. 4a).

In the May sampling, $N$. iodes occurred in all five levels; its greatest abundance is reported for station $\mathrm{A}$, where individuals of $O$. dama were also found. The sediment has characteristics very similar to those of the March sampling. No organisms associated with $N$. iodes occurred at station B, but $O$. dama, D. navicula and Mellita longfisa were recorded for station C. Only $N$ iodes was found at station D, and $N$. iodes, Diplodonta orbella, O. dama, Donax navicula and $M$. longfisa at station E (fig. 4b).

During the September sampling, $N$. iodes only occurred at levels B, C and D; D. navicula and $D$. orbella were observed at station $C$ and $M$. longfisa at station $\mathrm{D}$ (tig. $4 \mathrm{c}$ ). There is a notable increase in the grain size and occurrence of shells and shell fragments on the beach face, as well as an apparent change in the morphology of the profile, whereas at levels $D$ and $\mathrm{E}$, the sediment consisted of fine sand (2.65 to 2.8 phi)

Organisms were not found in the November sampling at stations $\mathrm{A}, \mathrm{B}$ and $\mathrm{C}$, where the sediment consisted of coarse sand. One specimen of $D$. navicula and one of Chione californiensis were reported for station D, where there was medium sand (1.9 phi). Donax navicula and six specimens of $M$. long/isa, its greatest abundance (table 4), were observed at station E, with fine sand (2.15 phi) (fig. 4d).

\section{Numerical classification}

A $Q$-mode cluster analysis was made, and the data from table 4 were standardized. The purpose of the standardization was to obtain a column by column matrix in order to give equal weight to each of the variables, using the equation $A=(A-$ minimum value $) /($ maximum value - minimum value), where $A$ is the corresponding column (Parks, 1966). Table 5 shows the standardized data to which the cluster analysis was applied.

Two clusters are observed for El Pelícano Beach in the March sampling (nig. 5a): one group consists of levels A1, B1, D1 and E1, and the other of only $\mathrm{Cl}$. The same pattern is 
a)

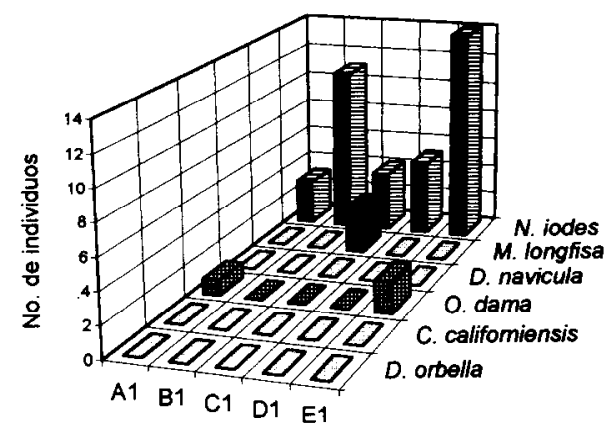

c)

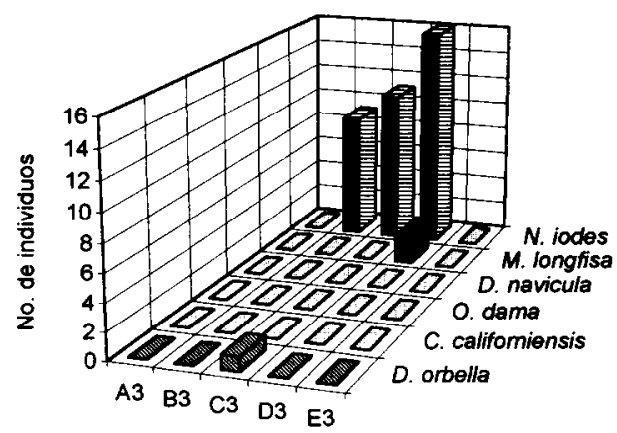

Estación
Marzo

Septiombre

Especies b)

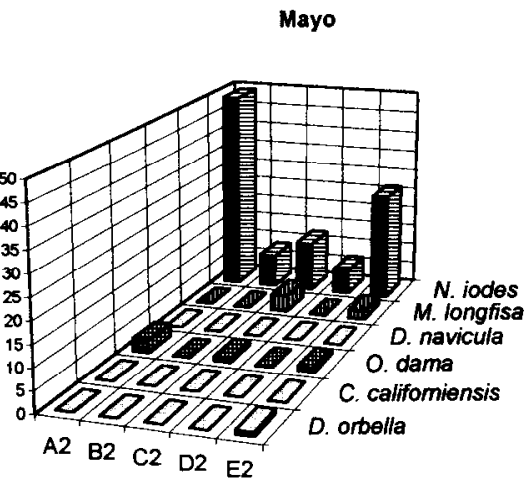

d)

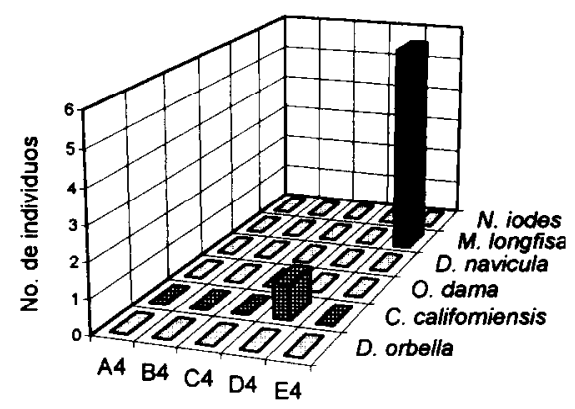

Estación

Especies

Figura 4. Ocurrencia de especies en las diferentes estaciones del perfil de playa, durante los diferentes meses de muestreo: (a) marzo, (b) mayo, (c) septiembre y (d) noviembre de 1993. La estación A corresponde a la cara de la playa; la estación $\mathrm{B}$, la planicie de marea interna; las estaciones $\mathrm{C}$ y $\mathrm{D}$, la planicie de marea media; y la estación E, la planicie de marea externa.

Figure 4. Species occurrence at the different stations of the beach profile, during the different sampling months: (a) March, (b) May, (c) September and (d) November 1993. Station A corresponds to the beach face; station $\mathrm{B}$, the internal tidal flat; stations $\mathrm{C}$ and $\mathrm{D}$, the middle tidal flat; and station $\mathrm{E}$, the external tidal flat.

En el muestreo de noviembre, en las estaciones $\mathrm{A}, \mathrm{B}$ y $\mathrm{C}$ no se encontraron organismos; el sedimento se mantiene en arenas gruesas. En la estación $\mathrm{D}$, con sedimento de arenas medias (1.9 phi), se encontró un individuo de $D$. navicula y uno de Chione californiensis, mientras que en la estación E (fig. 4d), de arenas finas (2.15 phi), se encontraron $D$. navicula y seis individuos de $M$. longfis $a$, lo cual representa su mayor abundancia a lo largo de todos los muestreos (tabla 4). observed in the May sampling (fig. 5b), but the dissimilarity of $\mathrm{C} 2$ is lower than that of the March sampling. There is a marked change during September (fig. 5c). There is a cluster of levels B3, D3 and C3, which in the previous samplings had shown great dissimilarity; the cluster formed by levels A3 and E3, which showed the greatest similarity, is completely removed and very different from this association. The results are different for the November sampling (fig. 5d). There is a cluster 
Tabla 4. Especies de macrofauna indentificadas durante los muestreos en Playa El Pelícano. Las letras representan las estaciones dentro del perfil de playa y los números, la fecha: $\mathrm{A}=$ cara de la playa, $\mathrm{B}=$ planicie de marea interna, $\mathrm{C}$ y $\mathrm{D}=$ planicie de marea media, $\mathrm{E}=$ planicie de marea externa; 1 = marzo de 1993, 2 = mayo de 1993, 3 = septiembre de 1993, 4 - noviembre de 1993.

Table 4. Macrofaunal species identified during the samplings at El Pelicano Beach. The letters represent the stations along the beach profile and the numbers, the date: $\mathrm{A}=$ beach face, $\mathrm{B}=$ internal tidal flat, $\mathrm{C}$ and $\mathrm{D}=$ middle tidal flat, $\mathrm{E}=$ external tidal flat; $1=\mathrm{March} 1993,2=\mathrm{May} 1993$, $3=$ September $1993,4=$ November 1993.

\begin{tabular}{|c|c|c|c|c|c|c|c|c|c|c|c|c|c|c|c|c|c|c|c|c|}
\hline Especies & Al & $\mathrm{Bl}$ & $\mathrm{C} 1$ & D1 & E1 & A2 & $\mathrm{B} 2$ & $\mathrm{C} 2$ & $\mathrm{D} 2$ & E2 & A3 & B3 & $\mathrm{C} 3$ & D3 & $E 3$ & $\mathrm{~A} 4$ & B4 & $\mathrm{C} 4$ & D4 & E4 \\
\hline 1. Diplodonta orbella & & & & & & & & & & 1 & & & 1 & & & & & & & \\
\hline 2. Nassarius iodes & 3 & 11 & 4 & 5 & 14 & 49 & 8 & 12 & 6 & 26 & & 9 & 11 & 16 & & & & & & \\
\hline 3. Olivella dama & 1 & & & & 2 & 3 & & 1 & & 1 & & & & & & & & & & \\
\hline 4. Donax navicula & & 1 & 2 & & & & & 2 & & 2 & & & 4 & & & & & & 1 & 1 \\
\hline 5. Mellita longfisa & & & 3 & & & & & 4 & & 2 & & & & 2 & & & & & & 6 \\
\hline 6. Chione californiensis & & & & & & & & & & & & & & & & & & & 1 & \\
\hline
\end{tabular}

Tabla 5. Matriz estandarizada de los datos de las especies de macrofauna identificadas durante los muestreos en Playa El Pelícano. Las letras representan las estaciones dentro del perfil de playa y los números, la fecha: $A=$ cara de la playa, $B=$ planicie de marea interna, $C$ y $D=$ planicie de marea media, E = planicie de marea externa; 1 = marzo de 1993, 2 = mayo de 1993; 3 = septiembre de 1993, 4 - noviembre de 1993.

Table 5. Standardized data matrix of the macrofaunal species identified during the samplings at El Pelícano Beach. The letters represent the stations along the beach profilc and the numbers, the date: $\Lambda$ - beach face, $B=$ internal tidal flat, $\mathrm{C}$ and $\mathrm{D}=$ middle tidal flat, $\mathrm{E}=$ external tidal flat; $1=\mathrm{March}$ 1993, 2 = May 1993, 3 = September 1993, 4 = November 1993.

\begin{tabular}{|c|c|c|c|c|c|c|c|c|c|c|c|c|c|c|c|c|c|c|c|c|}
\hline Especies & Al & $\mathrm{B} 1$ & $\mathrm{Cl}$ & Dl & E1 & $\mathrm{A} 2$ & $\mathrm{~B} 2$ & $\mathrm{C} 2$ & D2 & $\mathrm{E} 2$ & $\mathrm{~A} 3$ & B3 & $\mathrm{C} 3$ & D3 & E3 & A4 & B4 & $\mathrm{C4}$ & D4 & $\mathrm{E} 4$ \\
\hline 1. Diplodonta orbella & & & & & & & & & & 0.038 & & & 0.09 & & & & & & & \\
\hline 2. Nassarius iodes & 1 & 1 & 1 & 1 & 1 & 1 & 1 & 1 & 1 & 1 & & 1 & 1 & 1 & & & & & & \\
\hline 3. Olivella dama & 0.333 & & & & 0.142 & 0.061 & & 0.083 & & 0.038 & & & & & & & & & & \\
\hline 4. Donax navicula & & 0.09 & 0.5 & & & & & 0.166 & & 0.076 & & & 0.363 & & & & & & 1 & 0.166 \\
\hline 5. Mellita longfisa & & & 0.75 & & & & & 0.333 & & 0.076 & & & & 0.125 & & & & & & 1 \\
\hline 6. Chione californiensis & & & & & & & & & & & & & & & & & & & 1 & \\
\hline
\end{tabular}



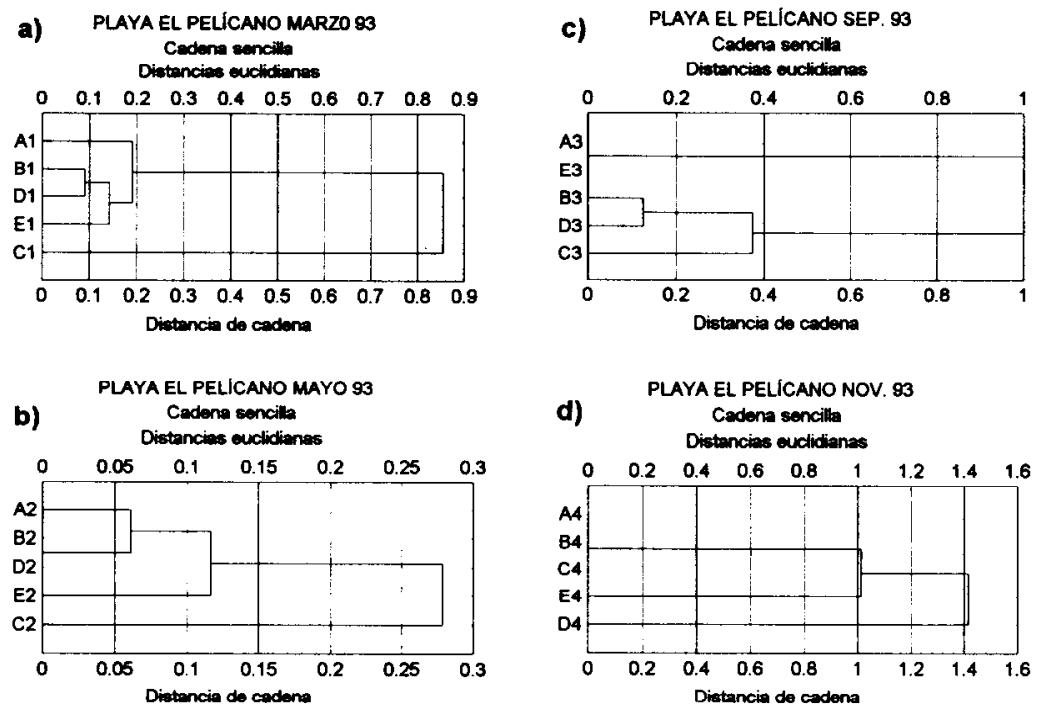

Figura 5. Dendrograma del análisis de agrupamiento modo $Q$ de Playa El Pelícano para los cuatro periodos de muestreo: (a) marzo, (b) mayo, (c) septiembre y (d) noviembre de 1993.

Figure 5. Dendrogram from the $Q$-mode cluster analysis of the four sampling periods at El Pelícano Beach: (a) March, (b) May, (c) September and (d) November 1993.

\section{Clasificación numérica}

Se realizó un análisis de agrupamiento en dendrograma modo $Q$ y se estandarizaron los datos de la tabla 4. La estandarización tuvo por objeto obtener una matriz columna por columna para dar un peso igual a cada una de las variables, utilizando la siguiente relación: $A=(A$ - valor mínimo $) /($ valor máximo - valor mínimo), donde $A$ es la columna correspondiente (Parks, 1966). La tabla 5 muestra los datos estandarizados a los cuales se les aplicó el análisis de agrupamiento.

En el muestreo de marzo de 1993 (fig. 5a), para Playa El Pelícano se observan dos agrupaciones: el primero formado por los niveles Al, $\mathrm{B} 1, \mathrm{D} 1$ y $\mathrm{E} 1, \mathrm{y}$ el segundo formado únicamente por la estación C1. En el muestreo de mayo de 1993 (fig. 5b), este patrón se mantiene, aunque se puede notar que la disimilitud de $\mathrm{C} 2$ es menor que en el muestreo de marzo. Para septiembre de 1993 (fig. 5c), el comportamiento cambia radicalmente y se puede observar una composed of $\mathrm{A} 4, \mathrm{~B} 4$ and $\mathrm{C} 4$ that presents high similarity, due to the fact that no organisms were collected from these levels; E4 and F4 have very low similarity.

Figure 6 shows all the samplings at El Pelícano Beach. Three clusters can be observed: one includes all the levels $(\mathrm{A}=$ beach face; $\mathrm{B}=$ internal tidal flat; $\mathrm{C}$ and $\mathrm{D}=$ middle tidal flat; and $\mathrm{E}=$ external tidal flat) for March, May and September; another consists of levels D4 and E4 from the November sampling; and the other is made up of A4, B4, C4, A3 and E3.

\section{DISCUSSION}

Most adaptive characteristics of sandy beach organisms are controlled by the changing environmental conditions, which are probably the most complex of the entire marine ecosystem (Brown and McLachlan, 1990). The environmental conditions of El Pelícano Beach consist of sediments dominated by coarse to medium sand, sorted into many coarse 
agrupación entre los niveles B3, D3 y C3, que en muestreos anteriores presentaban una disimilitud muy grande; alejados completamente de esta asociación y muy disímil entre ellos, se encuentra el grupo formado por los niveles A3 y E3, los cuales tienen la mayor similitud. Para el muestreo de noviembre de 1993 (fig. 5d), los resultados vuelven a ser diferentes; esta vez se nota una agrupación formada por A4, B4 y C4, que presentan una alta similitud debido a que en este muestreo no se recobró ningún organismo en estos niveles, mientras que E4 y F4 presentan una similitud muy baja.

En la fig. 6 se presentan todos los muestreos en Playa El Pelicano. Se pueden ver tres agrupaciones: una abarca todos los niveles $(A=$ cara de la playa, $B=$ planicie de marea interna, $C$ y $\mathrm{D}=$ planicie de marea media y $\mathrm{E}=$ planicje de marea externa) de los meses de marzo, mayo y septiembre; otra únicamente comprende el muestreo de noviembre en los niveles D4 y E4; y la tercera está formada por A4, B4, C4, A3 y E3.

\section{DISCUSIÓN}

La mayoria de las caracteristicas adaptativas de los organismos de playas arenosas están dictadas por las condiciones cambiantes del ambiente, probablemente las más complejas de todo el ecosistema marino (Brown y McLachlan, 1990). En Playa El Pelícano, estas características ambientales se traducen en sedimentos dominados por arenas gruesas a medias, cuya clasificación presenta muchos fragmentos gruesos (guijarros y conchas) que permiten una percolación del agua más rápida durante la bajamar, como en el caso de las estaciones A y B. Esta velocidad de percolación se incrementa debido a la pendiente abrupta de la cara de la playa (Komar, 1976). La alta porosidad de los sedimentos evita la retención de agua intersticial y el nivel freático se hunde, provocando una dilatación del sedimento, la cual evita que el sustrato sea fácil de penetrar por los organismos. En las estaciones C, D y E, la variación del tamaño de grano va de medio a fino, reflejando el cambio morfológico del perfil de playa. Cabe señalar que el perfil de playa presenta una fragments (pebbles and shells) that permit rapid water percolation during low tide, as is observed at stations A and B. Percolation speed increases due to an abrupt slope of the beach face (Komar, 1976). The high porosity of the sediments inhibits the retention of interstitial water and the phreatic level sinks, causing a sediment dilation that makes it difficult for the organisms to penetrate. At stations C, D and E, grain size varies from medium to fine, reflecting the morphologic change in the beach profile. It should be noted that the beach profile presents a wide berm and beach face with a pronounced slope that remain constant throughout the year. The pronounced slope of the beach face acts as a wall, against which the waves attack. This maintains a turbulent state in which only coarse sediments, such as whole shells and shell fragments, coarse sand and pebbles are deposited. This also causes more intense and quicker tidal currents, resulting in an environment in which the organisms are subject to processes that notably change the characteristics of the substrate which they inhabit and, consequently, the morphology of the beach profile.

With regard to the biotic environment, Nassarius iodes was widely distributed along the beach profile during the four sampling periods. It showed no preference for any particular station, since it was observed at the beach face (station $\mathrm{A}$ ), the middle tidal flat (stations C and D) and the external tidal flat (station E). Even though a zonation pattern has not been established for $N$. iodes, its behavior can be associated with its migratory habits, following the rise and fall of the tide along the beach profile, which allows the animal to remain in the swash zone, where there are optimum feeding conditions and it is protected from its predators (Brown and McLachlan, 1990).

The distribution of Olivella dama in the beach profile was irregular. Even though no organisms were collected during the September and November samplings, there was evidence of bioturbation. It appears that $O$. dama prefers the middle tidal flat and shallow regions of the shelf (Brown and McLachlan, 1990). 


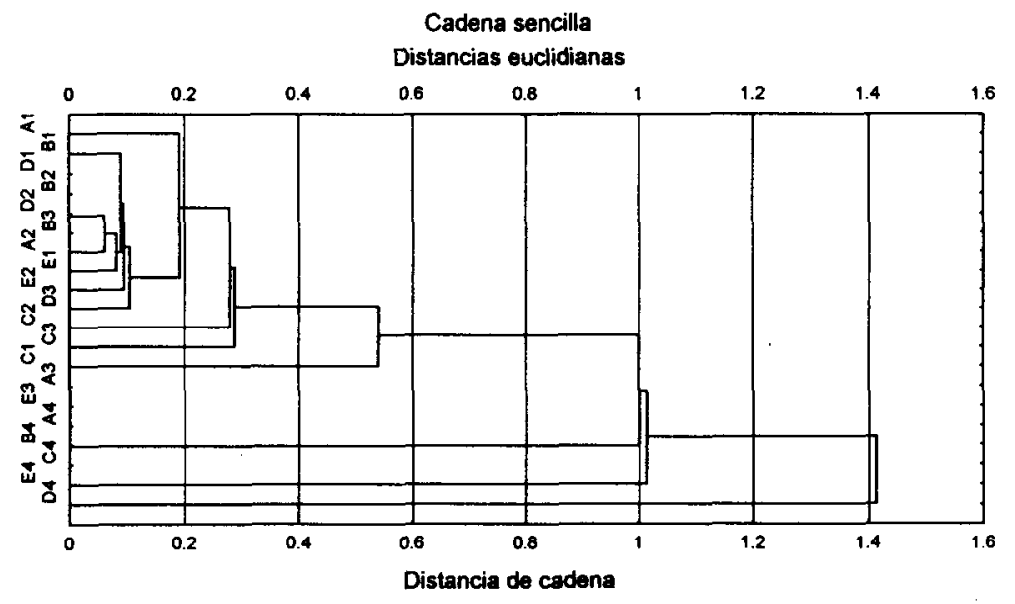

Figura 6. Dendrograma del análisis de agrupamiento modo $Q$ con todas las estaciones en los cuatro periodos de muestreo de Playa El Pelícano.

Figure 6. Dendrogram from the $Q$-mode cluster analysis of all the stations from the four sampling periods at El Pelícano Beach.

berma ancha y una cara de la playa de pendiente pronunciada, que se mantienen a lo largo de todo el año. Esta pendiente pronunciada de la cara de la playa actúa como una pared contra la cual chocan las olas, manteniendo un estado de turbulencia que sólo permite la depositación de sedimentos gruesos como fragmentos de conchas, arena gruesa y guijarros, así como conchas completas. Ésta también permite que las corrientes de marea sean más intensas y más rápidas, lo que se traduce en un ambiente en el cual los organismos están sujetos a procesos que cambian notahlemente las características del sustrato sobre y dentro del cual habitan $y$, en consecuencia, la morfología del perfil de playa.

En cuanto al ambiente biótico, Nassarius iodes presentó una amplia distribución a lo largo del perfil de playa durante los cuatro periodos de muestreo. No se observó un patrón preferencial hacia alguna estación, ya que lo podemos encontrar tanto en la cara de la playa (estación A), en la planicie de marea media (estaciones C y D), asi como en la planicie de marea externa (estación E). Aunque no existe un patrón definido en cuanto a su zonación, el comportamiento de $N$. iodes puede estar asociado con su comportamiento migratorio,
Another organism found was the sea cookie Mellita longfisa, which is a resident spccies. This organism apparently prefers fine sediments, since it occurred at station $\mathrm{C}$ during March and May, moving to stations $D$ and $E$ in September and November, because of the change in sediment from medium to coarse at station $C$, and from medium to fine at $D$ and $E$.

Based on the changes in the beach profile and species distribution, El Pelícano Beach has variable physical environmental characteristics throughout the year that regulate the variations in both the structure and zonation of the species. The response of the profile to external environmental conditions is reflected in the structural behavior of the macrobenthic community.

The clusters detected in the dendrograms varied according to the changes in species composition, resulting from fluctuations in the sedimentary and morphological characteristics of the beach profile and from the displacement of species along the profile due to their feeding habits.

Considering the above, the distribution of the organisms reflects distribution patterns that vary in space and time in high-energy sandy 
siguiendo el nivel de marea hacia arriba o hacia abajo sobre el perfil de playa. Lste comportamiento le permite al animal permanecer en la zona de vaivén del oleaje, donde las condiciones de alimentación son óptimas y se mantiene protegido de sus depredadores (Brown y McLachlan, 1990).

La distribución de Olivella dama a lo largo del perfil de playa fue irregular, ya que aunque no se recolectaron organismos durante los muestreos de septiembre y noviembre, en algunos niveles la evidencia de sus huellas de bioturbación fue patente. Al parecer, $O$. dama prefiere la planicie de marea media y regiones someras de la plataforma (Brown y McLachlan, $1990)$.

Otro organismo que se encontró es la galleta de mar Mellita longfisa, la cual es una especie residente. Al parecer, este organismo mantiene una preferencia por tamaños finos de sedimento, ya que se presenta en la estación $\mathrm{C}$ durante los meses de marzo y mayo, y se desplaza a las estaciones D y E en septiembre y noviembre, debido a que el sedimento cambia de medio a grueso en la estación $\mathrm{C}$, siendo de medio a fino en $\mathrm{D}$ y $\mathrm{E}$.

Con base en los cambios en el perfil de playa y en la distribución de especies, Playa El Pelícano presenta características fisicas del medio variables a lo largo del año que determinan variaciones tanto en la estructura como en la zonación de las especies. La respuesta del perfil a las condiciones extremas del medio se ve reflejada en el comportamiento de la estructura de la comunidad macrobentónica.

Las agrupaciones detectadas en los dendrogramas variaron de acuerdo con los cambios en composición de las especies, como consecuencia de las fluctuaciones en las características tanto sedimentarias como morfológicas del perfil de playa y del desplazamiento a lo largo del perfil de las especies, debido a sus hábitos alimenticios.

Considerando lo discutido con anterioridad, la distribución de los organismos refleja patrones de distribución variables en el espacio y tiempo en playas arenosas de alta energía, donde la baja diversidad y alta dominancia se pueden atribuir a las rigurosas condiciones beaches, where low diversity and high predominance can be attributed to the rigorous environmental conditions of the area, as established by Sanders $(1960,1968)$ in the stability-time hypothesis. This can be used in the interpretation of ancient beach deposits that should be characterized by a low diversity and high predominance of species. However, one must consider if the original structural characteristics are preserved, which is only possible when rapid burrowing occurs. These conditions can occur in transgressive or regressive sequences, but especially in the latter (Klein, 1974). In both cases, the local or regional fluctuations in the sea level play an important role in their conservation (Kraft, 1971). Once the highenergy ancient intertidal beach deposits have been identified by their sedimentological characteristics, the distribution patterns of the species, like those reported here, can be used to define environmental gradients in terms of degree of tidal exposure, properties of the sediment and feeding habits of the organisms.

\section{CONCLUSIONS}

The beach face (station A) and the internal tidal flat (station B) present physical and textural characteristics of the sediment that, combined with the intense reflux currents, cause a state of dilation in the substrate and make this section of the beach profile a difficult place for organisms with a rapid-burrowing defense mechanism to survive. For this reason, the occurrence of organisms is very scarce through time. Regarding the middle and external flats, even though they present very large changes in volume throughout the profile, the textural characteristics of the sediment do not vary much; this allows the occurrence of resident species, like the sea cookie Mellita longfisa, that prefer fine-sand sediments (stations D and E.).

In general, the species composition changes with variations in the textural characteristics of the sediment and in the morphology of the beach profile. Even though organisms like Nassarius iodes are governed more by their feeding habits than by their substrate 
ambientales de este medio, como es establecido por Sanders $(1960,1968)$ en su hipótesis de estabilidad-tiempo. Esto puede potencialmente ser utilizado en la interpretación de antiguos depósitos de playa, los cuales deberán caracterizarse biológicamente por una baja diversidad y alta dominancia de especies. Sin embargo, para esto hay que considerar que se preserven las caracteristicas estructurales originales, lo cual sólo es posible cuando ocurre un sepultamiento rápido. Estas condiciones pueden presentarse en secuencias transgresivas o regresivas, particularmente en estas últimas (Klein, 1974). Fn ambos casos, las fluctuaciones locales o regionales del nivel del mar juegan un papel muy importante en su conservación (Kraft, 1971). Una vez identificados antiguos depósitos intermareales de playas de alta energía por sus características sedimentológicas, los patrones de distribución de especies, como los aquí presentados, pueden ser útiles en definir gradientes ambientales en función del grado de exposición al oleaje, las propiedades del sedimento y los hábitos alimenticios de los organismos.

\section{CONCLUSIONES}

La cara de la playa (estación A) y la planicie de marea interna (estación B) presentan características fisicas y texturales de los sedimentos, que combinados con las intensas corrientes de reflujo provocan un estado de dilatación del sustrato, haciendo de csta sccción del perfil de playa un ambiente difícil para la supervivencia de organismos cuya defensa es el rápido enterramiento. Por esta razón, la presencia de organismos es muy escasa en el transcurso del tiempo. En el caso de la planicie media y externa, aunque se presentan cambios muy grandes en el volumen del perfil, las características texturales del sedimento se mantienen sin mucha variación, lo que permite la existencia de especies residentes como la galleta de mar Mellita longfisa, preferentemente en sedimentos de arena fina (estaciones D y E).

En general, la composición de las especies cambió en función de las variaciones en las características texturales del sedimento y de la morfología del perfil de playa. Sin embargo, organismos como Nassarius iodes rigen más su preferences, it occurred in different sections of the beach profile.

The low diversity and variability of sandy beach community structures make the interpretation of coastal environments very complex, since they are associated with great biotic and abiotic space-time variability in the environmental conditions. This allows us to assume that high-energy ancient intertidal beach deposits should be characterized by a low diversity and predominance of very few species.

\section{ACKNOWLEDGEMENTS}

This study was financed by the project "Fósiles de Baja California" (No. 272) of the Facultad de Ciencias Marinas, Universidad Autónoma de Baja California. Our thanks to Guillermo Ávila, Rigoberto Guardado-France and Oscar E. González-Yajimovich for their help with the samplings.

English translation by Jennifer Davis.

comportamiento por sus hábitos alimenticios que por su preferencia al sustrato y se encontró en las diferentes secciones del perfil de playa.

La baja diversidad y lo variable de la estructura de la comunidad de una playa arenosa hacen que la interpretación del ambiente costero sea muy complejo, ya que esto se asocia con una gran variabilidad espaciotemporal de las condiciones ambientales, tanto en el aspecto biótico como abiótico. Lo anterior permite suponer que antiguos depósitos intermareales de playa de alta energía deberán caracterizarse por una baja diversidad y dominancia de muy pocas especies.

\section{AGRADECIMIENTOS}

El presente trabajo fue apoyado por el proyecto "Fósiles de Baja California" (No. 272) de la Facultad de Ciencias Marinas, Universidad Autónoma de Baja California. Sc agradccc a Guillermo Ávila, Rigoberto Guardado-France y Oscar E. González-Yajimovich su valiosa colaboración en los muestreos de campo. 


\section{REFERENCIAS}

Brown, A.C. and McLachlan, A. (1990). Ecology of Sandy Shores. Elsevier, $328 \mathrm{pp}$.

Folk, R. (1980). Petrology of Sedimentary Rocks. Hemphill, Austin, Texas, 182 pp.

Fürsich, T.F. and Flessa, K.W. (1987). Taphonomy of tidal flat molluscs in the northern Gulf of California: Paleoenvironmental analysis despite the perils of preservation. Palaios, 2: 543-559.

Hanson, H. (1989). Genesis: a generalized shoreline change numerical model. J. Coast. Res., 5(1): 1-27.

Klein, G. de V. (1974). Estimating water depths from analysis of barrier islands and deltaic sedimentary sequences. Geology, 2 : 409-412.

Komar, D.P. (1976). Beach Processes and Sedimentation. Prentice-Hall, New Jersey, 429 pp.

Kraft, J.C. (1971). Sedimentary facies patterns and geologic history of a Holocene marine transgression. Geol. Soc. Am. Bull., 82: 2131-2158.

McLachlan, A. and Hesp, P. (1984). Faunal responses to morphology and water circulation of a sandy beach with cusps. Mar. Ecol. Prog. Ser., 19: 133-144.

Parks, J. (1966). Cluster analysis applied to multivariate geologic problems. J. Sedimen. Petrol., 74(5): 703-715.

Rhoads, D.C. and Young, D.K. (1970). The influence of deposit-feeding organisms on sediment stability and community trophic structure. J. Mar. Res., 28(2): 150-178.

Sanders, H.L. (1960). Benthic studies in Buzzards Bay. Animal-sediment relationships. Limnol. Oceanogr., 3: 245-258.

Sanders, H.L. (1968). Marine benthic diversity: A comparative study. Am. Naturalist, 102: 243-282.

Souyhgate, H.N (1989). A nearshore profile model of wave and tidal current interaction. Coast. Eng., $13: 219-245$. 